\title{
Studi Inisial Potensi Video Game Sebagai Media Belajar Untuk Moral
}

\author{
Tony Wibowo ${ }^{1}$ \\ ${ }^{1}$ Sistem Informasi, Fakultas Ilmu Komputer, Universitas Internasional Batam \\ tony.wibowo@uib.ac.id
}

\begin{abstract}
Abstrak
Video game dengan naratif yang kuat menjadi salah satu cara mengembangkan video game. Dengan menggunakan isu dilema moral pada publik, beberapa game dikembangkan dengan isu sosial sebagai ide utama. Penelitian ini bertujuan untuk mencari bukti apakah video game bisa bertindak sebagai media belajar untuk moral secara spesifik sebagai studi inisial. Penelitian dilakukan dengan melakukan expos menggunakan video terhadap video game dengan naratif kuat pada 66 responden selama 20-32 hari dan memberikan kuesioner respon terhadap video game tersebut. Kodifiikasi dilakukan untuk menilai semua responden bertujuan untuk mengkuantifikasi respon yang didapatkan. Hasil penelitian menunjukkan bahwa konsensus setuju bahwa video game memiliki potensi menjadi media belajar moral yang lebih baik dari buku maupun film. Video game juga ditemukan mampu mempengaruhi moralitas responden untuk jangka pendek, namun tidak mampu mempengaruhi secara signifikan moralitas jangka panjang. Diperlukan penelitian lebih lanjut untuk mengetahui pengaruh video game terhadap moralitas pemain.
\end{abstract}

Kata kunci: video game; moralitas; media belajar

\section{Initial Study of Video Game Potential as Morality Learning Media Abstract}

Video game with strong narrative is becoming new pattern of developing video game. By Utilize real-life public moral dilemma, some video games are developed with such issues as main idea of narrative. This initial study intends to prove whether video game can act as specifically morality learning media. The research was conducted by exposing 66 respondents towards heavy-narrative video game for 20 to 32 days using gameplay video and gather responses using questionnaire everyday to respond about said video game. Codification method are used to quantify gathered responses. The result shown that the consensus is agree that video game can be potentially be a better morality learning media compared to books and movie. It also shows that video game can affect short-term morality of respondents but no indication towards significant changes in long term morality. Further studies need to be done to understand effect of video game towards player's morality

Keywords: Video game, Morality, Learning Media 


\section{Pendahuluan}

Video game adalah salah satu media yang sangat populer saat ini. Perkembangan video game berasal dari awal yang sederhana pada tahun 1958 dengan game Pong menjadi industri video game telah dijual dan menghasilkan lebih dari 24.5 milyar dolar pada tahun 2016 (Siwek, 2017). Popularitas ini juga dibuktikan dengan jumlah game yang dihasilkan semakin banyak pertahun baik oleh studio game besar maupun oleh indie developer. Di Amerika sendiri ada kurang lebih 2500 perusahaan yang bergerak di video game dan menampung lebih dari 200.000 pekerja (Takahashi, 2017).

Perkembangan industri video game berbanding lurus dengan jumlah para pemain video game. Menurut Bowman, Kowert, \& Cohen, (2015), orang bermain video game karena mampu membuat perasaan sosial dan kebersamaan dengan orang lain baik dimainkan secara kooperatif maupun kompetitif. Perkembangan smartphone dengan konten terbesarnya adalah video game, membuat video game semakin mudah diakses oleh semua kalangan mulai dari anak-anak sampai orang tua. Menurut penelitian Samaha \& Hawi, (2016), kecanduan smartphone bisa menurunkan performa akademis namun pada akhirnya mempengaruhi kepuasan hidup yang lebih meningkat.

Jenis video game yang dikembangkan juga semakin bervariasi. Salah satu video game yang semakin populer adalah video game yang memiliki konten naratif yang kuat. Naratif dalam video game dikembangkan untuk membuat video game lebih menarik. Video game akan terasa lebih imersif dengan adanya naratif (Rogers, Woolley, Sherrick, Bowman, \& Oliver, 2017). Video game yang memiliki naratif kuat dapat menjadi mekanik utama dalam video game. Misalnya pada game Mass Effect (Bizzocchi \& Tanenbaum, 2012), dimana naratif menjadi aspek yang membangun alur dari video game dan setiap pilihan akan mengarah ke hasil yang berbeda. Contoh lain seperti Life Is Strange yang dikeluarkan oleh Square-Enix, Heavy Rain dan Detroit Become Human yang dikeluarkan oleh Quantic Dream.

Dilema moral adalah konflik internal yang disebabkan oleh 2 nilai yang memiliki nilai keduanya positif atau negatif sehingga keputusan yang diambil akan memiliki hasil yang negatif yang manapun yang kita pilih (Krcmar \& Cingel, 2016). Salah satu dilema moral yang paling terkenal adalah Trolley Problem, dimana kita memilih menyelamatkan banyak orang dengan mengorbankan 1 orang atau menyelamatan 1 orang yang kita kenal tapi mengorbankan banyak orang lain yang tidak kita kenal 
(Keleman, Lugonja, Subotić, \& Dimitrijević, 2019). Penggunaan dilema moral telah banyak digunakan sebagai naratif dalam video game. Misalnya saja pada Life is Strange, dimana salah satu keputusan terbesarnya adalah apakah menyelamatkan teman terbaik anda tapi kota anda dihancurkan tornado dan sebaliknya. Keputusan tersebut sangat menggambarkan penerapan Trolley Problem dalam video game.

Salah satu studi terkait video game adalah bagaimana naratif dalam video game mempengaruhi manusia. Salah satu studi seperti penelitian Katsarov, Christen, Mauerhofer, Schmocker, \& Tanner, (2019) menyebutkan bahwa video game dapat membuat pemainnya lebih memiliki empati pada kelompoknya sendiri, menyadari norma dan aturan dan menyadari bahwa dirinya sendiri mudah dipengaruhi oleh bias dan stigma tertentu. Penelitian lainnya dari Schuldt, Sachse, Hetsch, \& Moss, (2018) menyebutkan video game dapat mempengaruhi tindakan pemain bahkan di dunia nyata, dimana pilihan yang diambil di video game juga menunjukkan pilihan di dunia nyata.

Indonesia adalah negara yang menarik dari segi penetrasi video game. Pembajakan video game dan lemahnya hukum di Indonesia terkait hal tersebut membuat mayoritas pemain video game di Indonesia memiliki akses ke jumlah video game yang cukup besar karena tidak dibatasi oleh finansial (Alexandri, Maulina, Chan, \& Sumadinata, 2019). Penggunaan video game di Indonesia juga mulai beragam seperti di bidang edukasi (Ng, 2019), budaya (Pane, Najoan, \& Paturusi, 2017) dan arsitektur kota (Chkartina et al., 2019). Batam adalah salah satu daerah terluar dari Indonesia dan memiliki posisi yang sangat strategis karena berbatasan langsung dengan Singapura dan Malaysia sehingga gaya hidup di Batam cukup mirip dengan kedua negara tetangga tersebut, membuat Batam menjadi daearah yang menarik karena tidak hanya memiliki karakteristik demografi seperti orang Indonesia namun juga Singapura dan Malaysia (Aritenang, 2017). Tujuan utama penelitian ini adalah menjawab apakah video game dapat menjadi media pembelajaran moral bagi pemain di Indonesia, khususnya di batam.

Penelitian didasarkan pada hasil dan metode penelitian sebelumnya. Penelitian yang menjadi dasar utama penelitian ini adalah penelitian Iten, Bopp, Steiner, Opwis, \& Mekler, (2018) yang dilakukan untuk membukti hubungan antara perilaku pada video game dan perilaku di kehidupan nyata, terutama dalam perilaku menolong orang 
lain. Terbukti dilingkungan video game, pengguna yang secara sadar dan sukarela menolong pemain lain bahkan dalam game kompetitif sekalipun, juga menunjukkan perilaku yang sama di kehidupan nyata (dibuktikan dalam eksperimen sosial). Selain itu Katsarov et al., (2019) juga membuktikan dalam penelitiannya bahwa elemen video game, khususnya pada naratif video game juga menunjukkan dapat menstimulus senstivitas moral pada penggunaanya, kendati harus dilakukan dalam kondisi terkendali. Penelitian tersebut mendukung hasil penelitian Yang, Gang, \& Bae, (2016) yang menemukan pilihan tindakan dalam game merefleksikan tindakan dan cara pikir pemain di kehidupannya dengan menggunakan metode self-reporting.

Metode Self-Reporting adalah sebuah metode dimana setiap responden merespon secara mandiri pertanyaan maupun kegiatan yang memiliki jawaban openended. Secara umum metode ini lebih sulit untuk dikuantifikasikan karena harus dikodifikasi menjadi angka tertentu dimana menjadi tujuan penelitian sebelum bisa diuji datanya. Namun metode self-reporting memberikan kebebasan bagi responden menjawab dengan bebas sesuai kognitif dan afektif yang diketahui dan dirasakan sehingga sangat bernilai untuk sebuah studi inisial yang seperti kami lakukan (Iten et al., 2018; Krcmar \& Cingel, 2016; Yang et al., 2016).

\section{Pembahasan}

Penelitian yang akan kami lakukan melibatkan 66 Mahasiswa dan Profesional muda dengan usia diantara 18-25 tahun. Mahasiswa dan Professional muda ini semuanya memiliki relasi atau sering berhubungan dengan orang luar negeri baik karena kapasitas pekerjaan, hubungan sosial maupun keluarga terutama dengan Singapura. Responden juga memiliki pemahaman yang umum terhadap video game namun mengidentifikasi dirinya sebagai bukan pemain game secara aktif. Jenis responden ini sangat cocok untuk penelitian awal ini karena tidak terekspos dengan video game. Dari 66 responden tersebut akan dibagi menjadi 3 kelompok dimana masing masing kelompok akan melihat gameplay secara penuh dari sebuah game yang mengandung dilema moral: Life is Strange, Heavy Rain dan Detroit Become Human.

Setiap responden akan menjawab kuesioner awal yang terdiri dari pendapat responden mengenai isu moral pada awalnya, dilanjutkan ekspos kepada responden terhadap video game setiap hari. Pada akhir video, responden diminta mengisi 
kuesioner mengenai pendapat tentang dilema moral yang ada dalam video game dengan tindakan yang seharusnya diambil. Setiap responden diekspos dengan video game selama 20-32 hari tergantung kelompok dan pada akhirnya mengisi kuesioner akhir yang kembali menanyakan pendapat responden mengenai isu moral.

Hasil penelitian akan dianalisis dari 2 sisi yakni: 1) membandingkan perbedaan antara kondisi sebelum dan sesudah terekspos video game. Perbedaan ini diukur dengan melakukan kuesioner yang menilai pandangan responden terhadap hubungan sosial, kepemilikan, nilai pribadi dan isu global. Analisis juga dilakukan dalam bentuk: 2) melihat seberapa tinggi pengaruh video game terhadap pengguna dengan menggunakan kodifikasi dari jawaban setiap kuisioner dalam 5 kategori: pro-hukum (Law-oriented), pro-kebebasan (Freedom-oriented), demi kebaikan sendiri (Personal Advantage), demi kebaikan orang lain (Social Advantage) dan demi kebaikan publik (Public Advantage), yang kemudian diuji silang dengan hasil jawaban kuisioner akhir.

Dari total 66 responden tersebut, 14 terpapar game Life is Strange, 25 terpapar Heavy Rain, dan 27 terpapar Detroit: Become Human. Perbandingkan kondisi sebelum dan sesudah terpapar video game dilakukan dengan mengukur perbedaan antara hasil pertanyaan antara kuesioner sebelum dan sesudah. Tabel 1 menunjukkan perubahan yang terjadi untuk semua responden antara sebelum dan sesudah terpapar video game, untuk semua nilai yang diukur baik secara umum maupun setiap judul video game.

Tabel 1 Hasil Perbandingan Pandangan Responden Sebelum dan Sesudah Terpapar Video Game

\begin{tabular}{|l|c|c|c|c|}
\hline \multirow{4}{*}{ Parameter } & Umum & $\begin{array}{c}\text { Life Is } \\
\text { Strange }\end{array}$ & $\begin{array}{c}\text { Heavy } \\
\text { Rain }\end{array}$ & $\begin{array}{c}\text { Detroit: } \\
\text { Become } \\
\text { Human }\end{array}$ \\
\hline \multicolumn{4}{|c|}{ Hubungan Sosial } \\
\hline Orang Tua & $7.69 \%$ & $0.00 \%$ & $8.00 \%$ & $11.11 \%$ \\
\hline Saudara & $26.15 \%$ & $7.69 \%$ & $36.00 \%$ & $25.93 \%$ \\
\hline Keluarga & $43.08 \%$ & $38.46 \%$ & $40.00 \%$ & $48.15 \%$ \\
\hline Pasangan & $43.08 \%$ & $30.77 \%$ & $52.00 \%$ & $40.74 \%$ \\
\hline Teman & $32.31 \%$ & $7.69 \%$ & $44.00 \%$ & $33.33 \%$ \\
\hline Teman Masa kecil & $49.23 \%$ & $46.15 \%$ & $40.00 \%$ & $59.26 \%$ \\
\hline Teman Main & $33.85 \%$ & $53.85 \%$ & $16.00 \%$ & $40.74 \%$ \\
\hline Kolega & $36.92 \%$ & $38.46 \%$ & $40.00 \%$ & $33.33 \%$ \\
\hline \multicolumn{5}{|c|}{ Kepemilikan } \\
\hline Karir & $29.23 \%$ & $30.77 \%$ & $32.00 \%$ & $25.93 \%$ \\
\hline Iman & $27.69 \%$ & $38.46 \%$ & $36.00 \%$ & $14.81 \%$ \\
\hline Posisi/Jabatan & $40.00 \%$ & $23.08 \%$ & $44.00 \%$ & $44.44 \%$ \\
\hline Keahlian & $27.69 \%$ & $7.69 \%$ & $36.00 \%$ & $29.63 \%$ \\
\hline Pendidikan & $36.92 \%$ & $46.15 \%$ & $32.00 \%$ & $37.04 \%$ \\
\hline Keuangan & $40.00 \%$ & $23.08 \%$ & $44.00 \%$ & $44.44 \%$ \\
\hline
\end{tabular}




\begin{tabular}{|l|c|c|c|c|}
\hline \multicolumn{1}{|c|}{ Parameter } & Umum & $\begin{array}{c}\text { Life Is } \\
\text { Strange }\end{array}$ & $\begin{array}{c}\text { Heavy } \\
\text { Rain }\end{array}$ & $\begin{array}{c}\text { Detroit: } \\
\text { Become } \\
\text { Human }\end{array}$ \\
\hline Waktu & $16.92 \%$ & $15.38 \%$ & $16.00 \%$ & $18.52 \%$ \\
\hline Kesehatan & $7.69 \%$ & $7.69 \%$ & $12.00 \%$ & $3.70 \%$ \\
\hline Hobi & $46.15 \%$ & $23.08 \%$ & $52.00 \%$ & $51.85 \%$ \\
\hline \multicolumn{4}{|c|}{ Nilai Pribadi } \\
\hline Percaya Diri & $20.00 \%$ & $15.38 \%$ & $12.00 \%$ & $29.63 \%$ \\
\hline Kejujuran & $20.00 \%$ & $23.08 \%$ & $24.00 \%$ & $14.81 \%$ \\
\hline Kerja Keras & $26.15 \%$ & $38.46 \%$ & $24.00 \%$ & $22.22 \%$ \\
\hline Harga Diri & $40.00 \%$ & $46.15 \%$ & $32.00 \%$ & $44.44 \%$ \\
\hline Rasa Hormat oleh Orang Lain & $56.92 \%$ & $53.85 \%$ & $60.00 \%$ & $55.56 \%$ \\
\hline Pengorbanan Diri & $27.40 \%$ & $15.38 \%$ & $52.00 \%$ & $14.81 \%$ \\
\hline \multicolumn{3}{|c|}{ Pandangan Isu Global } \\
\hline Rasisme & $37.08 \%$ & $23.08 \%$ & $40.00 \%$ & $48.15 \%$ \\
\hline Kekerasan pada Anak & $18.46 \%$ & $23.08 \%$ & $12.00 \%$ & $22.22 \%$ \\
\hline Bullying & $32.31 \%$ & $23.08 \%$ & $40.00 \%$ & $29.63 \%$ \\
\hline Kesehatan Mental & $36.92 \%$ & $30.77 \%$ & $54.00 \%$ & $33.33 \%$ \\
\hline Kesenjangan Sosio-Ekonomi & $50.77 \%$ & $30.77 \%$ & $52.00 \%$ & $59.26 \%$ \\
\hline Obat Terlarang & $35.38 \%$ & $23.08 \%$ & $44.00 \%$ & $33.33 \%$ \\
\hline LGBTQ & $31.75 \%$ & $64.13 \%$ & $20.00 \%$ & $11.11 \%$ \\
\hline Terorisme & $18.46 \%$ & $15.38 \%$ & $24.00 \%$ & $14.81 \%$ \\
\hline Total & $\mathbf{3 1 . 5 1 \%}$ & $\mathbf{2 7 . 8 8 \%}$ & $\mathbf{3 4 . 5 2 \%}$ & $\mathbf{3 2 . 1 4 \%}$ \\
\hline
\end{tabular}

Pada tabel tersebut video game secara umum dapat mengubah, meski tidak signifikan, persepsi responden dengan nilai rata-rata perubahan sebesar $32.08 \%$. Perbedaan secara detail yang cukup besar dimana lebih dari 50\% ada pada perubahan pandangan pada rasa hormat dari orang lain dan pandangan pada isu sosio-ekonomi. Perubahan pada pandangan terhadap rasa hormat konsisten terjadi di semua video game, namun secara umum menurun tingkat prioritasnya menjadi tidak begitu meninggikan rasa hormat terhadap diri sendiri dari orang lain. Komentar responden seperti "Memperoleh kepercayaan dari orang lain tidak lah mudah. Dan bukan hal yang tepat kita menghianati orang lain dengan begutu mudahnya" mengindikasikan ada perubahan paradigma pada rasa hormat dari orang lain harus diperoleh terlebih dahalu. Sedangkan perubahan pada isu socio-ekonomi cukup, meningkat terutama pada game Heavy Rain dan Detroit: Become Human yang salah satu isu terbesarnya adalah isu kesenjangan sosial. Komentar responden seperti “Kondisi Markus dan para android seperti orang yang tidak memiliki rumah dan menunggu shutdown, rasanya seperti dunia kita, kita kadang menganggap pengemis itu bukan manusia, seperti pada 
game ini" menunjukkan bahwa responden memiliki perubahan pandangan dari segi isu sosio-ekonomi.

Secara umum, terdapat perubahan namun perubahan yang terjadi meski hanya mencapai 25\% saja. Dan ada beberapa pertanyaan yang bahkan tidak mengalami perubahan: pandangan pengenai orang tua, pandangan mengenai waktu, pandangan mengenai kesehatan, pandangan mengenai kepercayaan diri, pandangan mengenai kejujuran, pandangan mengenai isu kekerasan pada anak, dan isu mengenai terorisme. Pertanyaan tersebut berhubungan dengan norma masyarakat dan isu sosial yang cukup intens. Misalnya pada orang tua, dari 66 responden hanya 5 yang melaporkan adanya perubahan. Hal tersebut terjadi karena hampir semua responden melaporkan nilai maksimal untuk orang tua pada sebelum dan sesudah ekspos pada video game. Padahal pada game Heavy Rain salah satu naratif dan isu yang mau diangkat adalah kekerasan pada anak-anak oleh orang tua dan bagaimana orang tua mampu mengorbankan dirinya demi anaknya. Hal ini menarik apabila dikaitkan dengan pandangan mengenai isu kekerasan pada anak-anak yang juga tidak mengalami perubahan.

Dari masing-masing game, perubahan yang terjadi pada video game Life is Strange adalah persahabatan dan LGBTQ. Pada Heavy Rain adalah pengorbanan diri orang tua dan Kesehatan mental; Detroit: Become Human adalah kesenjangan sosial dan rasisme; dapat dikatakan bahwa tidak ditemukan bukti yang cukup kuat untuk menyatakan bahwa video game dapat mengubah pandangan terhadap moral. Life is Strange mengubah pandangan responden mengenai teman masa kecil dan persahabatan hampir 50\%. Pada kasus Heavy Rain, 54\% yang melaporkan perubahan pada pandangan terhadap Kesehatan mental. Dan Detroit: Become Human cukup memiliki pengaruh terhadap isu kesenjangan sosial dan juga rasisme tidak ada perubahan yang signifikan.

Terdapat beberapa temuan menarik dari hasil penelitian ini. Pandangan terhadap pacar/pasangan pada game Heavy Rain mendapat perubahan yang signifikan yakni sebesar 52\% lebih besar dari Detroit: Become Human dan Life is Strange kendati porsi romansa ada pada ketiga game, namun paling besar adalah pada Heavy Rain yang sebenarnya tidak menonjolkan hal tersebut. Hal in terjadi karena isu romansa yang dibawahkan oleh kedua game lain adalah romansa yang tidak klasik (Life is Strange pasangan lesbian yang mana menyebabkan perubahan yang signifikan pada pandangan 
responden pada LBGTQ dan Detroit: Become Human pasangan robot). Pandangan terhadap teman masa kecil juga mengalami perubahan signifikan diseluruh game menunjukkan secara umum video game dikorelasikan dengan teman masa kecil, beberapa responden menyebutkan teman ketika SD dan SMP dalam kuesionernya. Pandangan terhadap sahabat sangat kentara terlihat pada Life is Strange dan Detroit: Become Human yang keduanya cukup menunjukkan konten persahabatan dan tidak terlalu terlihat pada Heavy Rain. Berikutnya adalah pandangan pada keahlian yang mana pada Life is Strange karakter utama memiliki kemampuan membalikkan waktu sehingga setiap kesalahan bisa diperbaiki mendapat respon yang cukup negatif dan tidak mengubah pandangan responden, berbeda dengan Heavy Rain dan Detroit: Become Human yang menunjukkan kemampuan diri dan keahlian dalam memecahkan masalah.

Hasil pengujian kedua adalah hasil kodifikasi dari responden terhadap video game perhari (Lihat Tabel 2). Kodifikasi dilakukan dengan membaca semua komentar dan respon dari responden terhadap video yang dipetakan terhadap 5 parameter utama. Parameter pro-hukum diukur dengan setiap komentar yang membela hukum, peraturan dan otoritas pemerintah dengan +1 dan sebaliknya dengan nilai -1 . Parameter prokebebasan diukur dengan setiap komentar yang membela kebebasan dan hak asasi seperti kebebasan berbicara dan bertindak dengan +1 dan sebaliknya dengan nilai -1 . Untuk parameter demi kebaikan sendiri, demi kebaikan orang lain dan demi kebaikan publik juga mendapat nilai +1 untuk semua komentar yang memuji tindakan yang dilakukan demi diri sendiri, demi orang lain atau demi kebaikan umum dengan +1 dan memuji tindakan yang sebenarnya merugikan diri, orang lain atau publik dengan -1 .

Kodifikasi terhadap demi hukum memiliki hasil karena pada video game yang menunjukkan petugas hukum sebagai oknum yang tidak bertanggung jawab dan menjadi peran antagonis pada Detroit: Become Human mendapatkan nilai yang paling rendah (AVG: 4.74) beberapa responden malah melaporkan hasil yang negatif. Pada Heavy Rain dimana kita berperan sebagai detektif yang baik namun memiliki masalah dengan drugs dan mantan detektif yang adalah pembunuh sesungguhnya nilainya cukup berragam (AVG: 6.36), namun rata-rata masih positif. Pada Life is Strange dengan berfokus pada rasa ketidakpercayaan pada otoritas oleh pemeran utama yang dibuktikan dengan salah satu peran antagonis (yang kebetulan adalah petugas 
keamanan) ternyata adalah orang yang menyelamatkan kita mendapat nilai yang paling tinggi (AVG: 8.79) dengan banyak responden yang menjadi simpati terhadap karakter tersebut padahal sebelumnya memberikan pandangan negatif.

Ketiga game memberikan hasil pada nilai demi kebebasan yang berbeda; Life is Strange dengan kebebasan privacy dan seksual; Heavy Rain dengan kebebasan berekspresi; dan Detroit: become Human dengan isu kebebasan dari rasisme. Pandangan responden cukup menarik, karena tidak begitu terlihat seperti pada pandangan terhadap hukum. Dengan nilai rata-rata umum terendah $(A V G=1.39)$ dan bahkan melaporkan nilai negative untuk game Life is Strange yang mana konsisten dengan hasil pertama dimana game ini mengubah pandangan terhadap LGBTQ. Hal ini menunjukkan isu LGBTQ masih dipandang negatif di kalangan responden. Isu kebebasan rasisme, yang dalam hal ini ditunjukkan dengan ras robot pada Detroit: Become Human menunjukkan bahwa meski isu rasisme mempengaruhi $25 \%$ dari responden namun karena ras yang dibicarakan bukan manusia tidak mendapat perubahan yang cukup tinggi.

Tiga penilaian berikutnya yakin kebaikan diri sendiri, kebaikan orang lain dan kebaikan publik memiliki hasil yang sangat menarik. Isu terbesar dari Life is Strange adalah pertanyaan moral issue yang pertama dicetuskan dalam bentuk modern oleh Phillipa Todd pada 1967 yakni 'Trolley Problem' (Hübner \& White, 2018) yang dalam game ini ditampilkan dalam bentuk apakah anda akan menyelamatkan Chloe, teman kecil anda yang sekarang juga adalah calon pasangan hidup yang potensial atau menyelamatkan Arcadia Bay atau penduduk 1 kota. Dari 14 responden, bahwa pandangan ini terbelah menjadi 2 yang sama: 7 orang menyelamatkan Chloe dan 7 lagi menyelamatkan Arcadia Bay. Ini menjadi bukti bahwa Trolley Problem adalah dilemma moral yang mana tidak ada sulit untuk dicari konsensusnya.

Pada Heavy Rain yang ide utamanya adalah pengorbanan diri demi anak menunjukkan hal yang sama. Heavy Rain melaporkan nilai yang sangat rendah, yakni -1.84 pada kebaikan diri dimana responden menunjukkan simpati pada pengorbanan diri yang dilakukan dan ditampilkan pada video game. Kontras dengan respons yang tinggi seperti pada Life is Strange karena ada beberapa responden yang menyalahkan karakter untuk tidak langsung ke polisi saja daripada mengorbankan diri. Dan pada Detroit: Become Human hal ini menjadi sangat kentara karena karena isu kebaikan diri 
dan golongan ditunjukkan pada simpati oleh responden (Sendiri: 12.85, Orang Lain: 13.70). Namun pada game Detroit: Become Human melaporkan kebaikan publik yang tidak terlalu tinggi (2.96) karena proses revolusi robot yang dilakukan pada game tersebut menunjukkan otoritas dan publik dalam pandangan yang negatif. Dari hasil penelitian yang kedua menunjukkan bahwa video game bisa mempengaruhi moral atau pendapat moral dari responden. Hal ini bertolak belakang dengan hasil sebelumnya dimana secara umum video game belum bisa mengubah moral responden secara signifikan. Hal ini terjadi karena pengaruh waktu dari responden. Penelitian pertama ditujukan untuk pandangan moral jangka panjang karena berbicara mengenai isu moral secara umum; sedangkan penelitian kedua untuk jangka pendek karena responden diminta untuk merespon video game yang baru mereka lihat.

Tabel 2 Hasil Kodifikasi

\begin{tabular}{|l|c|c|c|c|c|}
\hline \multicolumn{1}{|c|}{ Game } & Hukum & Kebebasan & $\begin{array}{c}\text { Kebaikan } \\
\text { diri }\end{array}$ & $\begin{array}{c}\text { Kebaikan } \\
\text { orang lain }\end{array}$ & $\begin{array}{c}\text { Kebaikan } \\
\text { publik }\end{array}$ \\
\hline Semua & 6.21 & 1.39 & 6.77 & 12.77 & 5.09 \\
\hline Life is Strange & 8.79 & -1.14 & 10.43 & 16.43 & 12.00 \\
\hline Heavy Rain & 6.36 & 0.40 & -1.84 & 9.72 & 3.52 \\
\hline $\begin{array}{l}\text { Detroit: become } \\
\text { Human }\end{array}$ & 4.74 & 3.63 & 12.85 & 13.70 & 2.96 \\
\hline
\end{tabular}

Hal ini menjadi sangat menarik apabila kita melihat hasil responden terhadap pendapatnya mengenai video game. Dengan menggunakan skala likert, responden secara umum melaporkan pendapat mengenai video game dan pengaruh dari video game. Pada Tabel 3 menunjukkan hasil yang positif (vg: 4.11; vg effect: 3.42) dengan hampir $80 \%$ menyatakan bahwa video game adalah media yang lebih baik dalam menyampaikan Pendidikan moral dibanding buku, film atau musik karena interaktif dan ditampilkan dengan audio visual. Beberapa responden mengaitkan kejadian revolusi pada Detroid: Become Human dengan revolusi kulit hitam yang terjadi di amerika, dan isu SARA di Indonesia sendiri. Ada juga responden yang mengaitkan Heavy Rain dengan lakalantas karena kecerobohan pengemudi dan kelalaian orang tua, dan responden lain mengaitkannya dengan bagaimana polisi secara umum bertindak terlalu aman karena dikekang oleh hukum. Dan Life is Strange memberikan respon yang mengaitkannya bullying dikalangan pelajar, dan mayoritas responden melaporkan pernah menjadi korban bullying. 
Table 3 Respon terhadap Video Game

\begin{tabular}{|l|c|c|}
\hline \multicolumn{1}{|c|}{ Game } & Video Game & $\begin{array}{c}\text { Video Game } \\
\text { Effect }\end{array}$ \\
\hline Semua & 4.11 & 3.42 \\
\hline Life is Strange & 4.23 & 3.54 \\
\hline Heavy Rain & 3.76 & 3.24 \\
\hline $\begin{array}{l}\text { Detroit: become } \\
\text { Human }\end{array}$ & 4.37 & 3.52 \\
\hline
\end{tabular}

\section{Kesimpulan}

Video game sebagai media belajar moral sesuai dengan hasil yang didapatkan pada penelitian ini menunjukkan potensi yang cukup baik. Pengaruh yang ditimbulkan tidak cukup signifikan pada beberapa aspek namun respon yang positif terhadap penggunaan video game sebagai media yang baik dalam mempelajari moral sesuai dengan penelitian sebelumnya (Iten et al., 2018; Katsarov et al., 2019; Yang et al., 2016). Video game mampu mempengaruhi persepsi penggunaanya terhadap moral dalam jangka pendek namun belum menunjukkan hal serupa secara signifikan pada moral jangka Panjang. Respon yang didapat mengindikasi bahwa terdapat persepsi positif terhadap video game dan pengaruh dari video game, namun untuk melihat pengaruh video game terhadap pembelajaran moral secara umum masih perlu dilakukan studi lebih lanjut. Kekurangan dalam penelitian ini perlu dijawab dengan eksplorasi dan kuantifikasi dari bagaimana video game dapat mempengaruhi moralitas pemainnya masih perlu dijelaskan dengan studi mendatang.

\section{Referensi}

Alexandri, M. B., Maulina, E., Chan, A., \& Sumadinata, R. W. S. (2019). Creative Industries: Existence of Arts Traditional Industries in Indonesia. Academy of Strategic Management Journal, 18(1).

Aritenang, A. F. (2017). Special Economic Zone at the Crossroads: The Case of Batam. Jurnal Ilmu Sosial Dan Ilmu Politik, 21(2), 132. https://doi.org/10.22146/jsp.30438

Bizzocchi, J., \& Tanenbaum, J. (2012). Mass effect 2: A case study in the design of game narrative. Bulletin of Science, Technology \& Society, 32(5), 393-404.

Bowman, N. D., Kowert, R., \& Cohen, E. (2015). When the ball stops, the fun stops too: The impact of social inclusion on video game enjoyment. Computers in Human Behavior, 53, 131-139.

Chkartina, N., Budiman, A., Kreatif, F. I., Telkom, U., Bandung, I. K., \& Alam, D. (2019). Perancangan Konsep Environment Dengan Identitas Kota Bandung Untuk Video Game "Overgrown.” In e-Proceeding of Art \& Design (Vol. 6, pp. 3872-3879). 
Hübner, D., \& White, L. (2018). Crash algorithms for autonomous cars: How the trolley problem can move us beyond harm minimisation. Ethical Theory and Moral Practice, 21(3), 685-698.

Iten, G. H., Bopp, J. A., Steiner, C., Opwis, K., \& Mekler, E. D. (2018). Does a prosocial decision in video games lead to increased prosocial real-life behavior? The impact of reward and reasoning. Computers in Human Behavior, 89, 163172. https://doi.org/10.1016/j.chb.2018.07.031

Katsarov, J., Christen, M., Mauerhofer, R., Schmocker, D., \& Tanner, C. (2019). Training Moral Sensitivity Through Video Games: A Review of Suitable Game Mechanisms. Games and Culture (Vol. 14). https://doi.org/10.1177/1555412017719344

Keleman, A., Lugonja, L., Subotić, S., \& Dimitrijević, S. (2019). Trolley Problem: Psychopathy or Virtue? In Proceedings of The XXV Scientific Conference Empirical Studies In Psychology.

Krcmar, M., \& Cingel, D. P. (2016). Moral Foundations Theory and Moral Reasoning in Video Game Play: Using Real-Life Morality in a Game Context. Journal of Broadcasting and Electronic Media, 60(1), 87-103. https://doi.org/10.1080/08838151.2015.1127246

$\mathrm{Ng}$, J. (2019). Storytelling through Art: Teaching the History of Indonesia with Video Games. Art and Design Review, 7(1), 29-40. https://doi.org/10.4236/adr.2019.71004

Pane, B., Najoan, X., \& Paturusi, S. (2017). Rancang Bangun Aplikasi Game Edukasi Ragam Budaya Indonesia. E-Journal Teknik Informatika, 12(1). https://doi.org/10.35793/jti.12.1.2017.17793

Rogers, R., Woolley, J., Sherrick, B., Bowman, N. D., \& Oliver, M. B. (2017). Fun Versus Meaningful Video Game Experiences: A Qualitative Analysis of User Responses. The Computer Games Journal, 6(1-2), 63-79.

Samaha, M., \& Hawi, N. S. (2016). Relationships among smartphone addiction, stress, academic performance, and satisfaction with life. Computers in Human Behavior, 57, 321-325. https://doi.org/10.1016/j.chb.2015.12.045

Schuldt, J., Sachse, S., Hetsch, V., \& Moss, K. J. (2018). The Experimento Game: Enhancing a Players' Learning Experience by Embedding Moral Dilemmas in Serious Gaming Modules. In Online Engineering \& Internet of Things (Vol. 22). https://doi.org/10.1007/978-3-319-64352-6

Siwek, B. Y. S. E. (2017). Video Games in the 21st Century.

Takahashi, D. (2017). The U.S. game industry has 2,457 companies supporting 220,000 jobs. VentureBeat. Retrieved from https://venturebeat.com/2017/02/14/the-u-s-game-industry-has-2457companies-supporting-220000-jobs/

Yang, J.-W., Gang, S.-J., \& Bae, B.-C. (2016). A Study of the Effect of Character Perspectives on the Player's Moral Decision in Interactive Story. Journal of Korea Game Society, 16(6), 111-120. 